\title{
Vetenskaplig kunskap som problem för beslutsfattare och praktiker? Exemplet mässlingsvaccination.
}

\author{
FREDRIK BRAGESJÖ \& MARGARETA HALLBERG
}

\begin{abstract}
Artikelns syfte är att uppmärksamma problem som beslutsfattare och praktiker kan ställas inför när nya forskningsrön sprids. Problemen diskuteras utifrån de händelser som följde på publiceringen av en vetenskaplig studie som ifrågasatte de väletablerade rutinerna med mässlingsvaccinationer.
\end{abstract}

\section{Inledning}

I det ideala fallet anses vetenskaplig kunskap utgöra en god grund för utformandet av säker och sund praktik. Detta är t.ex. tanken bakom evidensbaserad vård och socialtjänst, där tillförlitlig och effektiv behandling bäst förmodas uppnås genom en vetenskapligt baserad verksamhet (Timmermans \& Berg 2003). Idealbilden innebär att vetenskaplig forskning alltid leder till, om än ibland på omständliga vägar, bättre

Fredrik Bragesjö är fil.dr. i vetenskapsteori vid Göteborgs universitet.

Margareta Hallberg är professor i vetenskapsteori vid Göteborgs universitet. och mer kunskap och att mer forskning så småningom kommer att utplåna eventuell osäkerhet. Vetenskapen förutsätts fungera bäst utan alltför stor inblandning av det övriga samhället och vetenskaplig kunskapsproduktion förstås $\mathrm{i}$ allt väsentligt som rationell och kumulativ. Förväntningarna på vad forskning kan åstadkomma blir därigenom stora.

För praktikers vidkommande kan idealbilden medföra flera problem. Ibland händer det att den kunskap som praktiker utgår från i sin yrkesutövning ifrågasätts, modifieras eller till och med visar sig vara felaktig. Istället för att utgöra den goda grund för handlande som idealbilden före- 
skriver, ökar osäkerheten om den vetenskapliga kunskapens nytta. ${ }^{1}$

I denna artikel hävdar vi att villkoren för vetenskaplig kunskapsproduktion är långt mer komplexa än idealbilden ger vid handen. Den behöver kompletteras, och grunderna till vetenskaplig kunskapsbildning behöver förstås teoretiskt och beskrivas empiriskt. En mer nyanserad syn på vad forskning är, hur kunskapsproduktion går till och hur forskningsresultat används finns inom fältet vetenskapsstudier (Collins \& Pinch 2005, Jasanoff 2004, Yearley 2005). Insikter härifrån är av central betydelse för att förstå de intrikata samband som finns mellan vetenskap och samhälle. ${ }^{2}$

1 Även sådan kunskap som betraktas som tillförlitlig kan emellertid generera problem för praktiker men då av ett annat slag. Introduktionen av t.ex. evidensbaserad medicin kan ifrågasätta den kompetens som tidigare baserats på erfarenhet och hota en yrkesgrupps autonomi.

2 Vi diskuterar denna utgångspunkt mer utförligt framgent under rubriken Vetenskapens sociala grunder. Det är emellertid viktigt att påpeka att denna position och syn på vetenskaplig kunskap skiljer sig från traditionella vetenskapsteoretiska uppfattningar som t.ex. verifikationism och falsifikationism. Vi hävdar att sociala faktorer alltid måste beaktas för att förstå den vetenskapliga processen. Det betyder att sådana faktorer inte ses som störande element som vetenskapen på alla sätt ska söka eliminera, utan de är en alltid närvarande aspekt att beakta i studier av vetenskapen. Dock menar vi självfallet att det finns skillnader mellan t.ex. religiös tro och vetenskaplig kunskap, men att verifikationistiska och falsifikationistiska vetenskapsteorier är ofullständiga för att lyckas fånga hela den komplexa vetenskapliga processen. För en god, men avancerad, introduktion till denna teoretiska utgångspunkt och syn på vetenskapen, se Barnes et al.1996.
Med avstamp i detta fält uppehåller vi oss empiriskt vid ett fall där vedertagen kunskap plötsligt sattes under debatt. Vi följer de händelser som följde på en studie som indirekt kom att ifrågasätta de väletablerade rutinerna med mässlingsvaccinationer. Studien, publicerad av en engelsk forskargrupp 1998, antydde att det kunde finnas en koppling mellan mässlingsvaccination och utveckling av autism hos småbarn. Resultatet blev en påtaglig variation i vaccinationsfrekvens i ett flertal länder $i$ västvärlden.

Artikelns syfte är att tydliggöra de processer som leder till osäkerhet och problem för beslutsfattare och praktiker, osäkerhet och problem som, menar vi, inte tacklas då den vetenskapliga kunskapsproduktionen ofta missförstås. Vi är givetvis medvetna om att praktiker $\mathrm{i}$ sin yrkesutövning återkommande fattar beslut men med beslutsfattande avser vi de vägledande direktiv som bestäms på politisk nivå. Vår artikel är baserad på litteraturstudier och fokuserar på praktikernas svårigheter men diskuterar även, och hämtar inspiration från tidigare forskning om, politiskt beslutsfattande. De villkor för vetenskapen som vi lyfter fram som betydelsefulla för att förstå praktikers problem har tidigare analyserats med avseende på politiska beslut (Collins \& Evans 2002).

Med vårt perspektiv framstår osäkerhet och kontroverser i vetenskapen som något naturligt och ofrånkomligt. Vi hävdar att mer realistiska förväntningar på vetenskapen skulle mildra de svårigheter som uppstår när praktik och beslut grundas i en alltför idealiserad syn på vetenskapen.

Fredrik Bragesjö \& Margareta Hallberg: Vetenskaplig kunskap som problem för beslutsfattare... 
Artikeln består av en empirisk del där fallet med mässlingsvaccination presenteras. Därefter visar vi varför detta fall inte är unikt utan måste betraktas som en följd av vetenskapens generella villkor.

\section{Mässlingsvaccination ifrågasatt}

\section{Allmänt om vaccinationer}

Syftet med att vaccinera är att i kontrollerad form stimulera kroppens immunförsvar att producera tillräckligt med antikroppar och därmed immunitet. Två saker uppnås med detta: dels skyddas individen mot en infektion, dels förhindras - om tillräckligt många $\mathrm{i}$ ett samhälle vaccineras - spridning mellan människor. Det senare brukar kallas "herd immunity", i fortsättningen kallat "massimmunitet». Om en viss procent av befolkningen är immun får infektionen inte möjlighet att sprida sig. Tanken med generella vaccinationsprogram är att uppnå massimmunitet och innebär således något mer än att ge skydd åt den enskilda individen. I fall där en viss sjukdom som inte är särskilt allvarlig för friska och starka individer kan vaccinationsprogram införas, dels för att skydda immunologiskt eller på annat sätt svaga personer, dels för att samhällskostnaden för en omfattande epidemi är väsentlig. När ett vaccinationsprogram genomförs innebär det således att ett smittsamt ämne injiceras i friska individer som vanligen inte riskerar allvarligare sjukdomssymtom eller men om han/hon utsätts för "naturlig" smitta. Att genomdriva generella vaccinationsprogram för därför med sig ett opinionsproblem, dvs. att övertyga friska och starka individer om betydelsen av vaccination, särskilt i de fall när det kollektiva minnet av en sjukdom (som i fallet med mässling efter ett par decennier av effektiv vaccination) fallit i glömska.

Världshälsoorganisationen, WHO, menar att utvecklingen av vaccin, tillsammans med teknik som ökat tillgången till rent vatten, är den innovation som i ett globalt perspektiv har haft störst positiv effekt på människans hälsa. Många miljoner människor undgår sjukdom och död på grund av framgångsrika vaccinationsprogram (WHO 2005). Mot denna bakgrund betraktas utvecklingen av vacciner och införandet av massimmuniseringsprogram vanligen som ett av medicinens stora framsteg under 1900talet.

Ibland har dock introduktionen av vaccination inneburit problem. I ett historiskt perspektiv är det sannolikt smittkoppsvaccinet under 1800-talet som rönt störst uppmärksamhet och kritik. En anti-vaccinationsrörelse etablerades t.ex. i Storbritannien under slutet av 1800-talet, där starka protester riktades mot kraven från myndigheternas sida på allmän vaccination av barn (Durbach 2005). Även i modern tid har det förekommit motstånd mot vaccinationer, t.ex. mot polio och kikhosta. I stort sett tycks emellertid vaccinationserbjudanden ha mottagits positivt av de flesta. I västvärlden har små barn vaccinerats $i$ mycket stor omfattning och vaccinationer har under lång tid varit tämligen okontroversiella. 


\section{Mässling och mässlingsvaccination}

Mässling är en mycket smittsam infektionssjukdom. I ett ovaccinerat samhälle drabbas i princip varje individ om smittan väl introduceras. Sjukdomen överförs från person till person och smittan är luftburen. Undernutrierade barn löper större risk att dö av sjukdomen än barn med goda näringsvärden, men också bland dessa kan sjukdomen vara allvarlig (Kaijser 1999 s. 135).

Den första generationen mässlingsvaccin utvecklades på 1960-talet samtidigt som vaccinationsforskningen över lag rönte stora framgångar (Kaijser $1999 \mathrm{~s}$. 12f). Introduktionen av vaccinet föregicks av ingående debatter, men sedan 1982 har dock svenska barn vaccinerats mot mässling samtidigt som de vaccineras mot påssjuka och röda hund i det allmänna vaccinationsprogrammet (Kallings \& Lundbäck 1999 s. 93).

På svenska kallas vaccinet MPR (mässling, påssjuka, röda hund). I Storbritannien förkortas det MMR (measles, mumps, rubella) och infördes 1988. Vaccinationen ges vid två tillfällen, dels vid 18 månaders ålder, dels vid tolv års ålder.

\section{Den vetenskapliga kontroversen}

Fram till 1998 var MPR-vaccinationen en av de flesta accepterad rutinmässig åtgärd. En artikel i den medicinska tidskriften The Lancet kom att ändra på detta. Omedelbart efter publiceringen seglade en kontrovers, dvs. en djupgående och påtaglig oenighet bland forskare, upp. ${ }^{3}$ Kontroversen handlade om en eventuell koppling mellan mässlingsvaccin och såväl autism som kronisk tarmsjukdom. ${ }^{4}$

Huvudförfattare till den aktuella artikeln var Andrew Wakefield, en brittisk läkare, men den undertecknades även av ett tiotal andra forskare och läkare. Studien omfattande tolv barn mellan tre och tio år som under sina första levnadsår hade haft en normal utveckling. Vid en viss ålder, som sammanföll med tidpunkten för MPR-vaccination, hade barnen emellertid förlorat tidigare förvärvade kognitiva och sociala förmågor samt uppvisat symtom som diarré och buksmärtor (Wakefield et al. $1998 \mathrm{~s}$. 637).

Buk- och tarmproblem hade således observerats hos barn som samtidigt uppvisar autistiska symtom. Problemen kan,

3 Vad som utgör en legitim vetenskaplig kontrovers kan förstås diskuteras. Vi arbetar här med en definition som tar fasta på den initiala och starka oenigheten på argumentationsnivå som fanns mellan forskarna. I denna artikel studeras företrädelsevis de omfattande effekter som en - i tid - förhållandevis kort kontrovers kan förorsaka. Som blir tydligt nedan finns det idag en övervägande majoritet som är kritiska till studien och påståendena av Wakefield et al., men enigheten är än idag inte total. Att aktörer med intressen i kontroversen idag kan betrakta den som historiskt övergående och vederlagd betyder inte någon svårighet att analysera den som en kontrovers med vidsträckta konsekvenser. För en mer elaborerad diskussion av kontroversbegreppet och kontroversstudier, se Hallberg \& Bragesjö 2003.

$4 \mathrm{Vi}$ analyserar kontroversen som en enskild episod men den är sannolikt kopplad till en allmän vaccinationskritik (intervju med P. Olin 2006). 
menar artikelförfattarna, härröra från de spår av mässlingsvirus som hittats i buken på barnen; att barn bär på mässlingsvirus kan i sin tur vara ett resultat av vaccination. Författarna betonar dock att de inte har funnit en kausal koppling mellan MPR-vaccinationen och det syndrom som de beskriver. En sådan koppling återstår att påvisa. Ett sätt att få kunskap om en möjlig koppling, hävdar de, är att undersöka i vilken utsträckning autistiska diagnoser har ökat efter 1988 då vaccinet introducerades i Storbritannien (Wakefield et al. 1998s. 641).

I samband med publikationen hölls också en presskonferens. Redaktören för The Lancet, Richard Horton, menar att den anordnades för att förklara innebörden av forskningsresultaten, för att undvika missförstånd och för att betona svårigheten med att dra definitiva slutsatser av studien. Det gick emellertid inte alls som planerat. Vid presskonferensen hävdade Wakefield att det fanns tillräcklig evidens för att, som en försiktighetsåtgärd, åtminstone separera de tre vaccinen (Horton 2004b s. 24). Även om han uppmanade till fortsatt vaccination, tog han avstånd från det vaccinationsprogram som innebar att tre vaccin ges vid ett och samma tillfälle.

Åtskillig kritik har riktats mot Wakefields slutsatser (för referenser, se nedan). Dels har det påpekats att de barn som Wakefield studerade inte var slumpvis utvalda utan fall där föräldrarna själva satt barnens problem i samband med vaccination. Dels har det framhållits att barn som utvecklar autism vanligen uppvisar symtom på sjukdomen vid just den ålder när MPR-vaccinet ges och att dessa därför kan sättas i samband med vaccinationen men att symtomen ändå skulle ha uppträtt (Moore 2005). Också The Lancet, där alltså originalartikeln förekom, har givit stort utrymme åt kritiska kommentarer och uppmaningar om fortsatta studier. 2004 publicerades t.ex. ett upprop av tio av de sammanlagt tolv medförfattarna till artikeln (Murch et al. 2004 s. 750). De tar avstånd från tolkningarna av forskningsrapporten från 1998, men ifrågasätter inte resultaten som sådana. I ett bemötande skriver Wakefield att resultaten av studien är korrekta och att de har bekräftats av oberoende forskare (Wakefield et al. 2004). Samma år publicerade redaktör Horton en ledare där han riktar sex anklagelser mot Wakefields artikel, bl a oredovisade intressekonflikter och otillbörlig finansiering (Horton 2004a).

Idag står emellertid Wakefield fortfarande fast vid sina hävdanden medan hans motståndares kritik är densamma. ${ }^{5}$

\section{Två typer avevidens}

Ett sätt att klargöra huruvida MPR-vaccinet innebär en ökad risk för autism är att undersöka om antalet rapporterade fall ökat efter introduktionen av vaccinet i Storbritannien 1988. Frågan besvaras enklast av den typ av populationsstudier som utförs av epidemiologer. Epidemiologen kan arbeta

5 Striderna kring mässlingsvaccinationen har på senaste tid tagit en delvis ny inriktning när en möjlig koppling mellan thimerosal, ett kvicksilverpreparat för vaccinkonservering, och autismutveckling förts fram (se t.ex. Kirby 2005). Den vetenskapliga uppmärksamheten har emellertid varit sparsam. 
deskriptivt, analytiskt och/eller åtgärdsorienterat (Giesecke 2003). I fallet med MPRvaccination handlar det dels om att införskaffa data om antal rapporterade fall av tarm- och autismproblem i en given population, dels huruvida en eventuell ökning kan sägas sammanfalla med introduktionen av nämnda vaccin i populationen.

I en kommentar från 1998 till Wakefield et al. presenteras argumentet att miljoner människor har vaccinerats bevisligen utan att autism utvecklats (Chen \& DeStefano 1998). Flera epidemiologiska studier har även gjorts som visat detsamma. I den första större analysen från 1999 presenterar Brent Taylor med kolleger resultat som talar mot en kausal koppling. De menar att det inte var fråga om en markant ökning av autismfallen efter införandet av MPR-vaccinet (Taylor et al. 1999).

De kommande åren presenterades ytterligare epidemiologisk forskning som slog fast att vaccinet inte tycks bidra till autismutveckling (för ett litet urval, se Afzal et al. 2000, Fombonne \& Chakrabarti 2001, Meldgaard Madsen et al. 2002). Kopplingen mellan vaccination och autism har med stöd av dessa studier dementerats av både WHO och amerikanska National Institutes of Health (NIH).

Redan Taylor et al. är, emellertid, en för epidemiologin metodologisk brydsamhet på spåren: »This study does not rule out the possibility of a rare idiosyncratic response to MMR. However, if such an association occurs, it is so rare that it could not be identified in this large regional sample» (Taylor et al. 1999 s. 2026). I en översiktsstudie, utgiven av amerikanska Institute of Medicine 2001, lyfts detta också fram sam- tidigt som man avvisar en kausal koppling:

A consistent body of epidemiological evidence shows no association at the popula tion level between MMR vaccine and ASD [Autistic Spectrum Disorder]. [...] However, the committee notes that its conclusion does not exclude the possibility that MMR vaccine could contribute to ASD in a small number of children, because the epidemiological evidence lacks the precision to asses rare occurrences of a response to MMR vaccine leading to ASD [...] (Stratton 2001 s. 6)

Epidemiologerna kan alltså med säkerhet säga att om MPR orsakar autism så sker det ytterst sällan. De kan däremot inte hävda, eftersom de inte undersökt samtliga barn, att MPR aldrig har utlöst eller i framtiden kommer att utlösa autism. Det blir således en fråga om sannolikhet. Risken är närmare noll, men inte noll. Problemet gäller allmänt för denna typ av populationsstudier och är inte unikt för fallet med MPR-vaccination och autism. Även om det faktiskt aldrig har hänt att MPR har fått sådana konsekvenser, tillåter inte metoden att hävda att det aldrig kan ske.

Kliniskt baserad laboratorieforskning skulle däremot kunna visa en koppling mellan vaccination och utveckling av autism i enstaka fall. Sådan forskning skulle kunna hitta ett av dessa epidemiologiskt möjliga fall och visa att här, i detta fall, förefaller MPR ha orsakat autism. Att epidemiologiska studier inte visat någon koppling innebär inte några principiella vetenskapliga problem för laboratorieforskningen, bara att det sannolikt blir svårt att hitta individer där detta hänt.

Fredrik Bragesjö \& Margareta Hallberg: Vetenskaplig kunskap som problem för beslutsfattare... 
Även sådana laboratoriestudier har utförts. Bland annat rapporterade en amerikansk studie högre halter av antikroppar mot mässling hos autistiska barn än hos icke-autistiska (Singh et al. 2002, se även Kawashima et al. 2000). Det är dock viktigt att påpeka att dessa studier inte har kunnat styrka att MPR-vaccin leder till autism. Forskarna har snarare försökt peka på att omständigheterna kring mässlingsvirusets förekomst hos autistiska barn indikerar att området måste utforskas mer.

Poängen i ett vetenskapsteoretiskt sammanhang är att såväl epidemiologisk som laboratorieforskning har svårigheter att slutgiltigt uttala sig i frågan. Epidemiologen kan visa att det är osannolikt att ett barn utvecklar autism till följd av vaccination - utan att kunna utesluta att MPR någon gång har orsakat eller kommer att orsaka autism. Laboratorieforskaren kan visa att autistiska barn förefaller ha mer antikroppar mot mässlingsvirus än andra - utan att göra anspråk på att ha bevisat en kausal koppling. Forskningsresultaten är inte entydiga utan möjliga att tolka på olika sätt och kan leda till skilda slutsatser.

Kunskapens osäkerhet och de medförande riskerna i kunskapens applikation kan också, vilket är viktigt när det gäller frågan om spridningen till media och allmänhet, användas och exploateras av aktörer med intressen $\mathrm{i}$ kontroversen. Tillämpningen av medicinsk vetenskap kan aldrig bevisa fullkomlig riskfrihet. När oro väl fått fäste hos allmänheten har därför beslutsfattare och praktiker svårt att avvisa påpekande av möliga biverkningar utan att ge sig in i esoteriska teoretiska diskussioner om sannolikhet. Beslutsfattares och praktikers oförmåga att hantera och kommunicera denna osäkerhet och risk, vill vi framgent argumentera, innebär problem.

\section{Spridning och konsekvenser}

MPR-kontroversen åtnjöt omedelbart stor uppmärksamhet i Storbritannien. Forskningsresultaten kom att rapporteras i alla betydande nyhetsmedia i landet. På grund av den mediala och vetenskapliga turbulensen började mässlingsvaccinationerna, trots att de flesta studier inte gav stöd åt Wakefields slutsatser och ingen forskning hittills kunnat belägga att MPR-vaccinet kan orsaka autism, att minska i antal. Till att MPRdebatten väckte stort intresse i Storbritannien bidrog sannolikt den förtroendekris som kontroversen om Creutzfeldt-Jakobs sjukdom, dvs. den s.k. galna ko-sjukan, lett till under 1990-talet. Ironiskt nog bidrog sannolikt också de tidigare vaccinationsframgångarna under ett decennium till debattens spridning och konsekvenser: eftersom mässling är en sjukdom som allt färre har erfarenhet av pga. allmänna vaccinationsprogram kunde uppenbara och allvarliga autistiska problem kontrasteras mot, för en stark och frisk individ, ofta förhållandevis lindriga sviter av mässlingssmitta.

Som vi diskuterade inledningsvis motiverades emellertid införandet av generell vaccination mot mässling med svåra effekter på försvagade individer, sjukdomens oerhörda smittsamhet och de problem detta genererade på befolkningsnivå. När en studie genomfördes ett par år efter artikelns publicering var Storbritannien det enda landet i en europeisk jämförelse som 
hade lägre vaccinationsnivåer av MPR år 2002 än 1990. En följd blev att insjuknandet i mässling under början av 2000-talet ökade (Fleck 2003 s. 1124). I Storbritannien har således kontroversen både rönt stor uppmärksamhet och fått omedelbara konsekvenser för vaccinationstalen. Lika intressant är att den snabbt har spridit sig till de flesta västländer, så även till Sverige. Redan i februari 1998 rapporterades forskningsresultaten i svensk nyhetsmedia (se t.ex. Expressen 98/03/01, Dagens Medicin 98/05/12). Därefter har frågan med jämna mellanrum tagits upp och debatterats i dagspress och populärvetenskap (se t.ex. Dagens Nyheter 00/02/11, Forskning och framsteg 2002, Svenska Dagbladet 04/02/21). Granskande debattprogram (SvTs Reportrarna 99/09/07 samt TV4s Kalla fakta 00/10/26) var av stor betydelse för att ge frågan uppmärksamhet. De kommande åren fick den antydda kopplingen mellan autism och MPR-vaccinationen därtill ett par tydliga språkrör (se Carlshamre 2000, Swartz 2000).

Trots att uppmärksamheten här varit mindre omfattande har vaccinationsfrekvensen påverkats. I Sverige minskade andelen barn som fått MPR-vaccin efter 1998: Smittskyddsinstitutet rapporterar att vaccinationstäckningen låg på runt 95 procent under 1990-talet men 2002 hade siffrorna sjunkit till 88,5 procent (barn födda 1999). Från medicinskt håll betraktades denna nedgång som ytterst oroande eftersom gränsen för garanterad massimmunitet anses ligga just under 90 procent (Linde \& Johansen 2001). Sedan dess har vaccinationsfrekvensen återhämtat sig; barn födda 2002 vaccinerades nästan i lika hög utsträckning som före Wakefields studie (Smittskyddsinstitutet 2005 s. 24).

Utvecklingen i Storbritannien hotade befolkningens tillit till myndigheternas vaccinationsprogram. Man försökte därför omgående återupprätta förtroendet för MPR-vaccinet. Flera viktiga auktoriteter hänvisade till att vaccinationskritiken saknade sedvanlig vetenskaplig bevisning och hälsomyndigheternas inställning var tydlig: MPR-vaccinationen är säker och det finns ingen anledning att separera de tre vaccinen. De hänvisade såväl till brittiska läkarförbundet (British Medical Association) som till världshälsoorganisationen $\mathrm{WHO}$ för stöd (Moore 2005).

Föräldragrupper har från början varit viktiga aktörer i kontroversen och tillsammans med läkare, psykologer och andra professionella deltagit i debatter, utfrågningar och reportage. Den största och viktigaste föräldragruppen heter JABS (Justice, Awareness and Basic Support; hemsida: http://www.jabs.org.uk). Företrädare för JABS hade kontakt med Wakefield redan före publiceringen av artikeln 1998 (Fletcher 2001). JABS har därefter kontinuerligt försökt påverka myndigheterna utan att lyckas.

Föräldrar har inte bara uppvaktat olika myndigheter utan också vänt sig direkt till praktiker inom hälso- och sjukvården. Det är läkare, sjuksköterskor och barnmorskor som får möta oron från föräldrarna. Myndighetsföreträdare hänvisar till epidemiologiskt och statistiskt material till stöd för sin linje, medan JABS samlat både evidens för sin position och mängder av föräldrar som har kontakt med sjukvården.

I en studie av föräldrarnas upplevelser av

Fredrik Bragesjö \& Margareta Hallberg: Vetenskaplig kunskap som problem för beslutsfattare... 
MPR-vaccinationen skriver Maggie Evans med kolleger:

All parents felt that the decision about MMR was difficult and stressful, and experienced unwelcome pressure from health professionals to comply. Parents were not convinced by Department of Health reassurances that $M M R$ was the safest and best option for their children and many had accepted MMR unwillingly. [---] Parents wanted up-to-date information about the risks and benefits of MMR to be available in advance of their immunisation appointment. Many parents did not have confidence in the recommendations of health professionals because they were aware that GPs needed to reach immunisation targets. Most parents would, however, welcome more open discussion about immunisation with health professionals. (Evans et al. 2001 s. 904)

Myndigheterna försökte, genom att hastigt producera och distribuera informationsmaterial, bistå läkares och sjuksköterskors möten med föräldrar och öka deras kunskap om existerande forskningsresultat. Undersökningar visade också att företrädare för hälso- och sjukvården var osäkra vid möten med föräldrar och hade dålig kunskap såväl om MPR-kontroversen som om de grundläggande tankarna med vaccinationsprogrammen. En studie visade t.ex. att var fjärde läkare och mer än var tredje sjuksköterska inte kände tillräcklig trygghet för att helhjärtat ställa sig bakom vaccinationsprogrammet (Petrovic et al. 2001). Läkare reagerade dessutom negativt på myndigheternas informationskampanj som de uppfattade som över- drivet betonande av säkerheten (Heller 2001).

Med de sjunkande vaccinationstalen i Sverige vidtog också svenska myndigheter åtgärder; liksom i den brittiska kontexten försökte man här höja sjukhusanställdas medvetenhet och kunskap om kontroversen och ingjuta förtroende för det existerande vaccinationsprogrammet. Företrädare för svenska myndigheter menar att man i Sverige av tradition har ett annorlunda förhållningssätt än i Storbritannien när allmänhet och praktiker informeras. Medan brittiska myndigheter gärna intar en auktoritär attityd, eftersträvar man från svenskt håll snarare att ge information om kunskapsläget i syfte att uppnå samstämmighet (Olin 2006, Tüll 2006). I en kunskapsöversikt avsedd för hälsovårdspersonal från 2001, det år när nedgången i vaccinationer blev tydlig, skriver Socialstyrelsen explicit att den »biologiska kopplingen mellan mässlingsinfektion/vaccination, tarmsjukdom och följande autism saknar [...] vetenskaplig grund. [...] Epidemiologiska data talar också emot ett samband" (Socialstyrelsen 2001 s. 26f). Även Smittskyddsinstitutet avfärdar en möjlig koppling (Smittskyddsinstitutet 2005). Företrädare för svenska myndigheter framträdde i både vetenskapliga sammanhang och nyhetsmedia (Johansen 2002, Olin 2006, Tüll 2006). På lokal nivå informerades berörda praktiker om att ingen koppling mellan mässlingsvaccination och autism kunnat bekräftas i stora studier (se t.ex. landstinget i Kalmars informationsblad Smittfronten 2002 och barnhälsoenhetens BHV-bladet 2001, Örebro läns landsting).

Det är tydligt att praktikerna inom sjukvården hade en lika svår som central roll 
mellan myndigheter och föräldrar. Tilltron till vaccinationsprogrammen var hotad och berörda myndigheter försökte återskapa förtroendet genom att förmedla informationsmaterial om det aktuella kunskapsläget till allmänhet och sjukhuspersonal. Det ankom på praktikerna att implementera myndigheternas beslut att öka vaccinationstalen och övertyga föräldrar om det förnuftiga i att vaccinera sina småbarn. Läkare och sjuksköterskor som arbetar med vaccinationsprogram befann sig i en mittposition: myndigheterna vände sig till dem för att öka vaccinationstäckningen samtidigt som de fick svara på oroliga föräldrars frågor.

\section{Analys och diskussion}

MPR-kontroversen kan tjäna som exempel på de två omständigheter som, hävdar vi, resulterar i svårigheter för både beslutsfattare och de praktiker som ska verkställa de fattade besluten. Vi menar att såväl relationerna mellan vetenskap, media och samhälle som den vetenskapliga kunskapens sociala grunder är viktiga omständigheter för att förstå varför MPR-kontroversen utvecklades och fick de konsekvenser som den fick. $\mathrm{Vi}$ argumenterar avslutningsvis också att dessa omständigheter är generella för vetenskaplig kunskapsproduktion och att konsekvenserna av dem förvärras av en förenklad och idealiserad bild av vetenskapen.

\section{Vetenskap, media och samhälle}

Vetenskaplig kunskap är en integrerad del av det samtida samhället. Som medborgare är vi alla påverkade, direkt och indirekt, av vetenskap och vetenskapligt baserad teknik. Vetenskapen är genom sin betydelse därför också många gånger en medial händelse: den rapporteras, diskuteras och i vissa fall både den missförstås och förenklas. En forskningsrapport med tentativa slutsatser kan publiceras för att sedan omtalas som larmrapport. Journalistiska presentationer som bristfälligt karaktäriserar den publicerade forskningen förekommer. Detta kan såväl bero på medvetet journalistiskt arbete (s k sensationsjournalistik), som okunskap i vetenskapligt esoteriska frågor och/eller utrymmes- och tidsbegränsningar. Relationen mellan media och vetenskap bör dock inte förenklas och medias roll ska inte heller överdrivas.

Forskare kan även använda media för sina egna syften. Ibland frångår forskarna vetenskapssamhällets traditionella process med kollegers förhandsgranskning (peer review) och väljer att rapportera sina resultat direkt till media. Fenomenet brukar kallas "science by press conference" (se Lewenstein 1995). Att rapportera sin forskning på detta sätt kan förstås vara problemfritt. Det kan emellertid vara ett sätt att profilera sig själv, sin forskning eller ett forskningsområde som får oönskade effekter.

Ytterligare en besvärlig omständighet i relationerna mellan forskarsamhälle och media är att etablering av konsensus $i$ vetenskapliga sammanhang ofta är en invecklad och långsam process. Även om en studie publiceras i en välrenommerad tidskrift där traditionell förhandsgranskning skett är detta ingen garanti för att

Fredrik Bragesjö \& Margareta Hallberg: Vetenskaplig kunskap som problem för beslutsfattare... 
resultaten inte kommer att motsägas av andra studier. Ingenting felaktigt eller avvikande behöver ha skett för att också resultaten av god forskning i framtiden kommer att betraktas som inkorrekta. Vid tidpunkten för publicering är det många gånger osäkert vad konsensusuppfattningen $\mathrm{i}$ en vetenskaplig fråga kommer att bli och när den etableras (Collins 1992[1985]). Kollegial granskning är inte heller någon garant för att resultaten inte kommer att få en medial uppmärksamhet som kan förorsaka problem för beslutsfattare och praktiker.

Ett annat möjligt problem är att personer med starka intressen i en kontrovers kan exploatera såväl god och bristfällig mediarapportering som det osäkra kunskapsläget för sina egna syften. Med ny teknisk utrustning, som internet, har allmänheten idag lättare att knyta kontakter, organisera sig och samla in material. I fallet med MPR-kontroversen blev det dessutom tydligt att forskare engagerades som talesmän och frontfigurer för att ge vetenskaplig trovärdighet till föräldraorganisationernas kritik.

Det är en empirisk fråga att utröna vilka effekterna blir av medias samspel med myndigheter, intresseorganisationer och allmänhet. Exemplet med mässlingsvaccination visar tydligt på det komplexa sammanhang och de villkor som påverkar relationerna mellan vetenskap, media och samhälle. Forskningsnyheten färdades i detta fall fortare än konsensus uppnåddes inom det vetenskapliga samhället. Forskare, oftast epidemiologer, och myndighetsföreträdare var tidigt ute och kritiserade Wakefields studie. Konsensus om mässlingsvaccina- tionens ofarlighet etablerades förhållandevis snabbt. Trots det blev de samhälleliga effekterna tämligen omfattande. Media och intresseorganisationer spelade här en central roll för utvecklingen.

\section{Den vetenskapliga kunskapens sociala grunder}

Vetenskapens förhållande till media och samhälle är inte bara komplext och svårhanterat, den vetenskapliga kunskapen har dessutom alltid ett inslag av ofrånkomlig osäkerhet som, om man är omedveten om det, kan innebära större svårigheter än nödvändigt. Fältet vetenskapsstudier har undersökt vad som sker när påståenden om naturen etableras $\mathrm{i}$ vetenskapssamhället och, av skilda orsaker, kommer att uppfattas som sanning. Vetenskaplig kunskap ses som, med en vetenskapsteoretisk term, underbestämd. Det betyder att kunskapens innehåll aldrig är givet, alltid äskar förklaring och alltid hade kunnat vara annorlunda (Collins 1992[1985], se även Barnes et al. 1996, Yearley 2005).

Med detta perspektiv har Harry Collins gjort bruk av begreppet "tolkningsflexibilitet", ett begrepp som är särskilt användbart vid studier av vetenskapliga kontroverser. Data är alltid möjliga att tolka och dra slutsatser utifrån på mer än ett sätt utan att forskarna gör avsteg från etablerade, "vetenskapliga" metoder. Collins visar att tolkningar av naturvetenskapliga experiment bestäms av sociala omständigheter. Huruvida data kommer att betraktas som tillräckliga bevis förstås med hjälp av socio- 
logiska kategorier som position och trovärdighet (Collins 1992[1985]). ${ }^{6}$

I exemplet med mässlingsvaccination kan en variant av tolkningsflexibilitet diskuteras. De involverade forskarna försöker besvara frågan om vaccinet kan leda till utveckling av autism och kronisk tarmsjukdom. Med populationsstudier som grund hävdar epidemiologer att MPR-vaccinationen är säker. De måste dock acceptera att sådana studier inte kan utesluta att mässlingsvaccinet någon gång har orsakat autism. Enstaka fall är omöjliga att upptäcka med denna metodik. Huruvida den epidemiologiska forskningen anses kunna besvara frågan om vaccinet kan leda till autism, beror alltså på vilka krav som ställs på sannolikhet, vilken trovärdighet denna typ av forskning tillskrivs och hur välvilligt evidensen tolkas.

Kliniska forskare arbetar till skillnad från epidemiologer i direkt kontakt med patienter, i detta fall med autistiska symtom och/eller tarmproblem. Forskarnas laboratorieanalyser sägs ha kunnat fastslå att det ibland förekommer mässlingsvirus i mag- och tarmsystemet hos patienter med

6 Inledningsvis talade vi om en idealbild av vetenskapen. Det som vi här beskriver är ett annat och enligt oss mer nyanserat sätt att förstå vetenskaplig kunskapsbildning på och som i förlängningen problematiserar den idealbild som utgår ifrån att rationella metoder och gott vetenskapligt hantverk kan eliminera t.ex. vetenskapliga kontroverser. Begrepp som underbestämning och tolkningsflexibilitet visar att sociala faktorer alltid påverkar forskningen, såväl i fall där kunskapen är stabiliserad som instabil. För vidare diskussioner om detta hänvisar vi till de ovan nämna referenserna. dessa besvär. Här möts forskarna av andra problem: konstaterad förekomst av mässlingsvirus är inte ett bevis på att viruset är ensam eller ens bidragande orsak till att autism utvecklas. Det är till och med svårt att föreställa sig hur en kausal koppling överhuvudtaget skulle kunna bevisas i kliniskt baserad laboratorieforskning; ett oändligt antal alternativa förklaringar till uppkomsten av autistiska problem är förstås teoretiskt möjliga. Huruvida mässlingsviruset finns i mag-och tarmsystemet till följd av MPR-vaccinationen eller av naturliga orsaker är likaså ett problem. Såsom i fallet med epidemiologisk populationsforskning kan resultaten av laboratorieforskning tolkas till stöd för en möjlig koppling mellan MPRvaccinationen och autism men de är också möjliga att kritisera och avfärda.

Bedömningen av såväl epidemiologins som laboratorieforskningens tillförlitlighet är avhängig graden av välvillighet hos uttolkarna.

\section{Konsekvenserför beslutsfattare och praktiker}

Det vi ovan beskrivit innebär, som t.ex. Collins och Evans (2002) har visat, problem för beslutsfattare. Vetenskaplig kunskap förekommer ofta som beslutsunderlag för politiker och forskare figurerar flitigt som rådgivare och experter i utredningar. Problemet här är att tekniska beslut många gånger måste fattas innan konsensus bildats inom vetenskapen. Om forskare inte är överens utan involverade i en kontrovers, vem ska då beslutsfattarna lita på? Sheila Jasanoff har diskuterat liknande problem i

Fredrik Bragesjö \& Margareta Hallberg: Vetenskaplig kunskap som problem för beslutsfattare... 
samband med att vetenskapen dras in i det juridiska och politiska systemet (Jasanoff 2004). Hur får politiker, jurister och myndighetsföreträdare överhuvudtaget insikt i komplexa vetenskapliga frågor?

I fallet med mässlingsvaccinationer fick svenska politiker och myndigheter hantera och ta ställning till Wakefields artikel om en möjlig koppling mellan MPR-vaccinet och autism. Innan konsensus hade uppnåtts i det vetenskapliga samhället, började vaccinationsfrekvensen att sjunka till nivåer där mässlingsepidemier blev möjliga.

Samma omständigheter, menar vi, skapar även svårigheter för praktiker. Praktiker som läkare och sjuksköterskor har visserligen inte samma krav på att fatta tekniska beslut som politiker och myndighetspersonal, men de brottas likväl med liknande frågor. Praktikernas problem är tvådelat. Dels måste de hantera och bemöta den oro som skapats hos föräldrar och allmänhet av den vetenskapliga kontroversens offentliga förlopp och kunna fungera som rådgivare gentemot patienter. Dels måste de genom- driva de beslut som fattas av t.ex. myndigheter. I fallet med mässlingsvaccinationer handlade det om att ingjuta förtroende i vaccinationspolitiken och förhindra utbrott av epidemier utan att negligera föräldrarnas, och kanske även sina egna, farhågor.

\section{Konklusioner}

Med MPR-vaccination som exempel har vi diskuterat den vetenskapliga kunskapsproduktionens villkor. Genom att lyfta fram några av dess inneboende problem och samhällets inflytande på vetenskapen, har vi försökt visa att etablerade rutiner och kunskap alltid riskerar att, av goda eller mindre goda skäl, destabiliseras. Vi distanserar oss från uppfattningen att forskning en gång för alla kan lösa upp konflikter och skapa en stabil grund för våra antaganden om världen. Den leder till en orealistisk förväntan på vad forskning kan åstadkomma och kan slå över i besvikelse och kunskapsförakt om forskningen inte ger entydiga svar.

\section{Referenser}

Afzal MA, Armitage E, Ghosh S, Williams L C \& Minor PD (2000) "Further evidence of the absence of measles virus genome sequence in full thickness intestinal specimens from patients with Crohn's disease«. Journal of Medical Virology, vol. 62, s. 377-382.

Barnes B, Bloor D \& Henry J (1996) Scientific knowledge: a sociological analysis. London: Athlone.
BHV-bladet (2001), information från Barnhälsovårdsenheten, Örebro läns landsting, oktober 2001. http://orebroll.se/upload/Prim/Kansli/ BHV/Dokument/2001\%2010.pdf [2005-12-12].

Carlshamre, M (2000) „Var det vaccinet som skadade Erik?", Expressen, 2000-10-26, s. 3.

Chen, RT \& DeStefano, F (1998) "Vaccine at adverse events: Causal or coincidental?». The 
Lancet, vol.351, issue 9103, s. 611-612.

Collins, HM (1992[1985]) Changing order: replication and induction in scientific practice. With a new afterword. Chicago: The University of Chicago Press.

Collins, HM \& Evans, R (2002) «The third wave of science studies: studies of expertise and Experience». Social Studies of Science, vol. 32, number 2, s. 235-296.

Collins, HM \& Pinch, T (2005) Dr. Golem. How to think about medicine. Chicago: The University of Chicago Press.

Dagens Medicin (1998) "Ingen koppling mellan autism och sprutor». 1998-05-12, s. 1.

Dagens Nyheter (2000) "Mässling drabbar åter", 2000-02-11, s. A05.

Durbach, N (2005) Bodily matters: the anti-vaccination movement in England, 1853-1907. Durhem; London: Duke University Press.

Evans M, Stoddart H, Condon L, Freeman E, Grizzell M \& Mullen R (2001) „Parents' perspectives on the MMR immunisation: a focus group study". British Journal of General Practice, vol. 51, nr 472, s. 904-910.

Expressen (1998) „Brittisk larmrapport: Vanligt vaccin kan göra barn autistiska». 1998-03-01, s. 10.

Fletcher, J (2001) "Background notes on MMR and late onset Autism", 14 February 2001. http:// www.jabs.org.uk/pages/information.htm [2005-12-12].

Fleck, F (2003) "UK and Italy have low MMR uptake». BMJ. British Medical Journal, vol. 327, no 1142, s. 1124.

Fombonne, E \& Chakrabarti, S (2001) »No evidence for a new variant of measles-mumpsrubella-induced autism". Pediatrics, vol. 108, number 4, s. e58.

Forskning och framsteg (2002) "Allt färre barn vaccineras mot mässling". 2002-12-27, vol. 38, s. 28-31.

Giesecke, J (2003) „Epidemiologiska grundbegrepp«. K Ekdahl \& J Giesecke (red.) Smittskyddsboken. Lund: Studentlitteratur

Göteborgs Posten (2004) „Föräldrar väljer bort sprutornaw. 2004-04-17, del 1, s. 5.
Hallberg, M \& Bragesjö, F (2003) Konflikt eller konsensus? Om kontroversstudier som forskningsfält. Stockholm: Forskningsrådet för arbetsliv och socialvetenskap.

Heller, T(2001) "How safe is MMR vaccine?». BMJ. British Medical Journal, vol. 323, s. 838-839.

Horton, R (2004a) "A statement by the editors of The Lancet». The Lancet, vol. 363, issue 9411, s. $820-821$.

Horton, R (2004b) MMR, science and fiction: exploring the vaccine crisis. London: Granta Books.

Jasanoff, S (2004 red.) States of knowledge: the co production of science and social order. London: Routledge.

Johansen, K (2002) "MPR-vaccinet orsakar inte autism". Smittskydd, nr 6, s. 16.

Kaijser, B (1999) Vaccination i Sverige och övriga Norden. Andra upplagan. Lund: Studentlitteratur

Kalla fakta i TV4 (2000), "Den enda sanningen". Dyfvenmark, J \& Bergman, S, 2000-10- 26.

Kallings, L O \& Lundbäck, H (1999) „Statens Bakteriologiska Laboratorium (SBL) - en epok" Smittskydd, nr 9, s. 91-95.

Kawashima H, Mori T, Kashiwagi Y, Takekuma K, Hoshika A \& Wakefield, A (2000) „Detection and sequencing of measles virus from peripheral mononuclear cells from patients with inflammatory bowel disease and autism". Digestive Diseases and Sciences, vol. 45, nr 4, s. 723-729.

Kirby, D (2005) Evidence of harm: mercury in vaccines and the autism epidemic: a medical controversy. New York: St. Martin's press.

Linde, A \& Johansen, K (2001) "Vaccination mot mässling, påssjuka och röda hund har god skyddseffekt. Att avstå från att vaccinera skulle allvarligt hota vårt goda immuntetsläge». Läkartidningen, vol. 98, s. 3658-3664.

Lewenstein, BV (1995) „From fax to facts: communication in the cold fusion sagaw. Social Studies of Science, vol. 25, nr 3, s. 403-436.

Meldgaard Madsen K, Hviid A, Vestergaard M, Schendel D, Wohlfahrt J, Thorsen P, Olsen J \& Melbye M (2002) »A population based study of

Fredrik Bragesjö \& Margareta Hallberg: Vetenskaplig kunskap som problem för beslutsfattare... 
Measles, Mumps and Rubella vaccination and autism". New England Journal of Medicine, vol. 347 , nr 19, s. 1477-1483.

Moore, A (2005) opublicerad doktorsavhandling, Department of European Studies and Modern Languages, University of Bath.

Murch SH, Anthony A, Casson DH, Malik M, Berelowitz M, Dhillon A P, Thomson MA, Valentine A, Davies SE \& Walker-Smith JA (2004) "Retraction of an interpretation". The Lancet, vol. 363, issue 9411 , s. 750.

Olin, P (2006), intervju 2006-03-29, Smittskyddsinstitutet, Solna.

Petrovic M, Roberts R \& Ramsay M (2001) "Second dose of measles, mumps, and rubella vaccine: questionnaire survey of health professionals". BMJ. British Medical Journal, vol. 322, s. 8285.

Reportrarna i SvT (1999) „Vaccination för vem?». Tjernström, E \& Karlsson, H, 1999-09-07.

Singh VK, Lin SX, Newell E \& Nelson C (2002) "Abnormal measles-mumps-rubella antibodies and CNS autoimmunity in children with autism". Journal of Biomedical Science, vol. 9, nr 4, s. 359-364.

Smittskyddsinstitutet (2005) Epidemiologisk årsrapport 2004. Stockholm: Smittskyddsinstitutet.

Smittfronten (2002), nr 11, september 2002. http://www.ltkalmar.se/smittskyddet/ 1\%C3\%A4kare/smittfronten/sf_11-02.htm [2005-12-12].

Socialstyrelsen (2001) Vaccination av barn: vanliga frågor om säkerhet och effekter. En kunskapsöversikt för hälsovårdspersonal. Stockholm: Socialstyrelsen.

Stratton K, Gable A, Shetty P \& McMormick M (2001) Immunization safety review: MeaslesMumps-Rubella vaccine and autism. Immu- nization Safety Review Committee, Board on Health Promotion and Disease Prevention, Institute of Medicine. Washington, DC: National Academy Press.

Swartz, J (2000) "Är massvaccination mot mässling nödvändig?". Medikament, nr 5, s. 14 -19.

Svenska Dagbladet (2004) "Barnläkare i blåsväder». 2004-02-21, s. 17.

Taylor B, Miller E, Farrington CP, Petropoulos MC, Favot-Mayaud I, Li J \& Waight PA (1999) "Autism and measles, mumps, and rubella vaccine: no epidemiological evidence for a causal association". The Lancet, vol. 353, s. 20262029.

Timmermans, S \& Berg, M (2003) The gold standard: the challenge of evidence-based medicine and standardization in health care. Philadelphia, Pa: Temple University Press.

Tüll, P (2006), intervju 2006-03-29, European Centre for Disease Prevention and Control, Solna.

Wakefield AJ, Harvey P och Linnell J (2004) „MMR - responding to retraction". The Lancet, vol. 363, issue 9417 , s. 1327-1328.

Wakefield AJ, Murch SH, Anthony A, Linnell J, Casson DM, Malik M, Berelowitz M, Dhillon AP, Thomson MA, Harvey P, Valentine A, Davies SE \& Walker-Smith JA (1998) "Ileallymphoid-nodular hyperplasia, non-specific colitis, and pervasive developmental disorder in children". The Lancet, vol. 351, issue 9103, s. 637-641.

WHO (2005) »The history of vaccination«. http:// www.who.int/vaccines-diseases/history/history.shtml [2005-12-12].

Yearley, S (2005) Making sense of science: understanding the social study of science. Thousand Oaks, Ca; London: Sage. 


\section{Summary}

\section{Scientific knowledge as a problem for policy-makers and professionals? The MMR case}

Scientific research is generally considered the ideal basis both for well-informed political decisions and safe and sound practical health care. In this article, however, a different approach originating from Science and Technology Studies is used to demonstrate how an idealized view of scientific knowledge may also cause problems for policymakers as well as professionals. We discuss a controversy regarding the well-established vaccination programme against measles, mumps and rubella (MMR). In 1998, Dr Andrew Wakefield, head of a British research group, implied that there might be a link between the measles vaccine and the development of autism in children. After the publication, a prolonged and intense debate emerged both in scientific journals and in the media. The debate was followed by a decline in MMR vaccination numbers.

In this article we emphasize two types of conditions affecting the development of the controversy. Firstly, we argue that scientific knowledge is produced under theoretical conditions where observations, experiments and scientific methodology alone can never settle scientific disputes. We exemplify this by discussing the shortcomings of both epidemiology and laboratory research. Secondly, we argue that contemporary scientific knowledge is created under social conditions where the media play an important role in making public esoteric knowledge about which no scientific consensus has yet been reached. Consensus is usually formed slowly while news travels fast. Once the possible link between autism and the MMR vaccine had been suggested, these circumstances together created a difficult situation for both policymakers and professionals.

Our conclusion is that the problems illustrated by the MMR controversy are general and complicated to deal with for governmental representatives and health care practitioners. The problems are possibly also aggravated by an inadequate understanding of the realities of scientific knowledge production. 